\title{
A Study on Knowledge, Skills and Abilities of Labourers Affecting the Performance of Building Construction Projects in Sri Lanka
}

\author{
M. Kesavan, P.B.G. Dissanayake, C.K. Pathirana, M.M.D.R. Deegahawature and \\ K.D.R. Silva
}

\begin{abstract}
The successful completion of a construction project highly depends on the labour efforts and performance. In developing countries like Sri Lanka, the most important challenge faced by the construction industry is the low performance of labour operations. Sources reveal that the knowledge, skills and abilities (KSAs) of labourers significantly affect the performance of labour in the construction projects. This study is aimed to identify the critical KSAs of labourers which highly influence the performance of building construction projects in Sri Lanka. The significant KSAs of labourers were initially identified using qualitative thematic analysis method through a comprehensive literature review and a series of structured interviews conducted among construction experts in Sri Lanka. Using the snowball sampling method, a questionnaire survey was carried out among building construction projects in Sri Lanka to measure the severities of these KSAs on the performance of construction. A total of 154 contractors responded to this survey. The severities of the KSAs were measured by calculating their Relative Importance Index (RII) values. Overall, 13 knowledge areas and 28 skills/abilities of labourers were identified as critical based on their RII values. The results show that the industry should have more focus on improving the work-related cognitive and self-management skills of the labourers than their transferable and technical skills. The validity and reliability of the findings were ensured using relevant statistical tests. There were no significant differences found between the perceptions of the different levels of working categories on the identified KSAs. It is highly recommended to consider the critical KSAs identified in this study, when current practices are upgraded for construction labour force in the industry. The findings of this study are expected to be very useful to the Sri Lankan construction industry as well as other developing construction industries in similar scenarios.
\end{abstract}

Keywords: $\quad$ Building projects, Construction industry, Labour skills, Sri Lankan labourers

\section{Introduction}

Construction plays a major role in a country's economy. The economy is becoming more productive, more innovative and more competitive due to the existing human potential. Usage of the labour force is the major component for a successful completion of any construction project. The poor performance of labour has become one of the most daunting human resource problems in the construction industries of many countries, especially in developing countries [1].

In most developing countries, a great portion of construction labourers generally comes from poor education and economic background. Various labourers have different variables affecting their performance levels. Their levels of knowledge, skills and abilities (KSAs) vary in a wide spectrum. The performance of labourers can be improved through developing their KSAs. The KSAs of labourers can be developed through improving the practices on education and training, work methods, health facilities, motivational factors, use of tools and materials, work quality and some other labour related factors.

Eng. M. Kesavan, AMIE(SL), BSc Eng (Hons) (Peradeniya), AMSSE(SL), GREENSL®AP, Lecturer (Probationary), Department of Construction Technology, Faculty of Technology, Wayamba University of Sri Lanka.

Email:kesavan@wyb.ac.lk

(iD) https://orcid.org/0000-0002-1985-348X

Eng. (Dr.) P.B.G. Dissanayake, AMIE(SL), BSc Eng (Hons) (Peradeniya), PhD (Hong Kong), MIE(Aust), Senior Lecturer, Department of Civil Engineering, Faculty of Engineering, University of Peradeniya. Email:pujithad@gmail.com

Eng. (Dr.) C.K. Pathirana, C.Eng, MIE(SL), BSc Eng (Peradeniya), MSc Eng (Peradeniya), PhD (Peradeniya), MSSE(SL), Senior Lecturer, Department of Civil Engineering, Faculty of Engineering, University of Peradeniya.

Email:chinkupathi@gmail.com

Prof. M.M.D.R. Deegahawature, BSc (Business Administration) (Jayewardenepura), MBA (Colombo), MBA (Technology Management) (AIT), PhD (Huazhong), MIM(SL), Associate Professor, Department of Industrial Management, Faculty of Applied Sciences, Wayamba University of Sri Lanka. Email:dharsana@wyb.ac.lk

Prof. K.D.R. Silva, BSc (Agric) (Sri Lanka), PhD (UK), RNutr, The Director, Centre for Quality Assurance, Wayamba University of Sri Lanka. Email: renuka.silva@wyb.ac.lk 
Considering Sri Lankan perspective, the skill shortage of labourers was highlighted as one of the major problems in the building construction projects by Fernando et al. [2]. Construction Industry Sector Council (CISC) and Industry Sector Skills Councils (ISSC) of Sri Lanka also confirmed the absence of cognitive, soft and job specific technical skills among construction labourers as stated in the Construction Industry Sector Training Plan 2018-2020 of the Tertiary and Vocational Education Commission of Sri Lanka [3].

Sources indicate that the KSAs of Sri Lankan labourers are inadequate for the performance improvement in the building construction projects at present. Identifying the critical KSAs of labourers affecting performance with the severity measurements will be highly beneficial to the industry for taking necessary steps in construction related operations for the improvement. This study aimed to investigate on the KSAs of labourers influencing the performance improvement of the building construction projects in Sri Lanka.

\section{Literature Survey}

There are several studies conducted on the knowledge areas, skills/abilities and performance of the construction labourers in many countries. A study was investigated by Biren et al. [4] on the factors affecting labour performance in construction through a systematic review of recently published research articles. Labourers' poor knowledge of construction methods was identified as the major factor which influences the labour performance in the construction industry in many countries [4]. The same problem was highlighted by Mistry \& Bhatt [5], Parviz \& Mohammed [6] and Serdar \& Jasper [7] considering the construction projects in India, Iran and New Zealand, respectively.

Labourers' lack of commitment was identified as one of the key factors affecting labour performance in the construction industry in India by Saurav et al. [8]. Lack of commitment and poor attendance of labourers were identified by Mostafa \& Khaled [9] as the factors highly influencing the productivity of construction in Egypt. Poor attendance of labourers was found as one of the serious problems in the high-rise building projects in Indonesia by Peter et al. [10] and the same problem was stated by Jim \& Jahidul [11] considering the building construction projects of Singapore. Brent \& Leighton [12] found that punctuality of labourers is one of the significant factors affecting labour productivity in the building construction projects of Trinidad \& Tobacco. Communication skills of the Spanish labourers and their ability to adopt to the changes in the environment were found by Robles et al. [13] as specifically needed to be improved in the building projects in Spain. The attitude of the labourers was identified by Fernando et al. [2] and Orando \& Isbariye [14] as one of the major problems in the building projects in Sri Lanka and South Africa, respectively. Orando \& Isbariye [14] also highlighted the learning skills of labourers as needed to be improved in the building construction projects in South Africa and this was stated by Rasool \& Botha [15] too. Silva et al. [16] revealed that there is a requirement to improve the learning skills of Sri Lankan labourers. Labourer's psychological skills and abilities were highlighted by Dharani [17] and Aynur et al. [18] as specifically needed to be improved in the construction industry of India and Turkey, respectively.

From the project manager's viewpoint of factors affecting construction productivity in the State of Queensland, Australia, it was revealed that the labourers need to pay more attention to their health and safety practices [19]. The same problem was highlighted by Peter et al. [20] and Oseghale et al. [21] considering the building construction projects in Nigeria, Mistry \& Bhatt [5], Shahab \& Audrius [22] and Abdulaziz et al. [23] determined that the labourer's knowledge of health science and their physical abilities are very poor in the building construction projects in India, Lithuania and Qatar, respectively.

Oseghale et al. [21] assessed the skilled workforce in the Nigerian construction industry and revealed that the technical skills of labourers are needed to be improved, especially in brickworks, carpentry, plumbing and painting. Considering the building construction projects in Sri Lanka, Fernando et al. [2] highlighted that the technical skills of labourers on bar bending, brickworks plastering, tiling, carpentry and plumbing are specifically needed to be developed. Praveen et al. [24] revealed that there is a requirement to improve the skills of labourers on understanding of technical drawings and material handling in the building construction projects in Sri Lanka.

Overall, the literature review of this study reveals that there is a requirement to develop 
the KSAs of labourers for improving the performance of construction operations in Sri Lanka. But, there were not a sufficient number of studies focused on the KSAs of labourers in the Sri Lankan construction sector. This study intended to identify the significant KSAs of Sri Lankan labourers using qualitative and quantitative approaches with the scope of improving the performance of building construction projects.

\section{Preliminary Survey}

A preliminary survey was conducted through a comprehensive literature survey and a series of structured interviews to qualitatively identify the significant KSAs of labourers affecting the performance improvement in the Sri Lankan building construction projects.

\subsection{Literature Survey}

A comprehensive literature investigation was carried out through reviewing the academic articles published from 18 countries as shown in Table 1. Out of these, a total of 8 research articles were based on Sri Lankan perspective. The no. of research articles reviewed based on the published period is shown in Table 2. More than $80 \%$ of these articles were published in the last 10 years, with $40 \%$ published in the last 5 years.

Table 1 - No. of Reviewed Research Articles based on the Countries

\begin{tabular}{|l|c|}
\hline Country & $\begin{array}{c}\text { No. of Research } \\
\text { Articles }\end{array}$ \\
\hline India & 10 \\
\hline Sri Lanka & 8 \\
\hline Nigeria & 3 \\
\hline South Africa & 3 \\
\hline Indonesia & 2 \\
\hline Egypt & 2 \\
\hline Australia & 1 \\
\hline Iran & 1 \\
\hline Lithuania & 1 \\
\hline New Zealand & 1 \\
\hline Palestine & 1 \\
\hline Qatar & 1 \\
\hline Singapore & 1 \\
\hline Spain & 1 \\
\hline Trinidad \& Tobacco & 1 \\
\hline Turkey & 1 \\
\hline UK & 1 \\
\hline Vietnam & 1 \\
\hline
\end{tabular}

Table 2 - No. of Reviewed Research Articles based on the Published Period

\begin{tabular}{|l|c|}
\hline Period & $\begin{array}{c}\text { No. of Research } \\
\text { Articles }\end{array}$ \\
\hline $2016-2020$ & 16 \\
\hline $2011-2015$ & 17 \\
\hline $2006-2010$ & 4 \\
\hline $2001-2005$ & 1 \\
\hline Up to 2000 & 2 \\
\hline
\end{tabular}

Most of these research articles were initially selected through popular online search engines 'Google Scholar, 'World Wide Science' and 'Scopus' according to their reputation, impact rating and subject content. Some of the articles were found based on the recommendations provided by the subject matter experts. The keywords, title and abstracts of the articles were closely examined. The detailed review process was then carried out and a table was prepared to summarize the collected data from the literature review.

\subsection{Interviews}

Structured interviews were conducted among construction experts from the Sri Lankan construction industry to study the updated practices of the industry. A total of 42 construction experts participated in these interviews. Table 3 illustrates the work experience of the construction experts interviewed.

Table 3 - No. of Interviewed Construction Experts based on their Years of Experience

\begin{tabular}{|l|c|}
\hline $\begin{array}{l}\text { Years of Experience in } \\
\text { the Construction Field }\end{array}$ & $\begin{array}{c}\text { No. of } \\
\text { Interviewed } \\
\text { Construction } \\
\text { Experts }\end{array}$ \\
\hline Less than 5 Years & - \\
\hline $5-10$ Years & 16 \\
\hline $11-15$ Years & 04 \\
\hline $16-20$ Years & 07 \\
\hline $21-25$ Years & 03 \\
\hline More than 25 Years & 12 \\
\hline
\end{tabular}

The directors, project managers, engineers, quantity surveyors, institutional experts from training providers, supervisors and technical officers participated in these interview sessions. A total of 15 interviewees had work experience with foreign labour forces. A comparison of KSAs between Sri Lankan labourers and foreign labourers was also performed through these interviews. 
Comparing with the foreign labour forces, Sri Lankan labourers' knowledge of new technologies, health and safety practices, architectural concepts, quality assurance and controlling practices, construction methods and English language were identified as needed to be highly concerned. With the skills/abilities category, Sri Lankan labourers' attitude, commitment, punctuality, attendance, team working ability, ability to work in different climatic conditions, technical skills, learning skills, problem solving skills and tool handling skills were identified as lagging behind.

In addition, the following results were also obtained through the interviews conducted.

- $86 \%$ of the interviewees agreed that the knowledge of the Sri Lankan labourers is inadequate for the performance improvement in the building construction projects at present.

- $90 \%$ of the interviewees agreed that the skills and abilities of the Sri Lankan labourers are inadequate for the performance improvement in the building construction projects at present.

- Majority of the interviewees stated that the construction companies/organizations are not providing adequate training facilities to develop the KSAs of labourers in the Sri Lankan construction sector.

\subsection{Thematic Analysis}

Thematic analysis method was applied on the identified KSAs from the preliminary survey. As Caulfield [25] stated, thematic analysis is a good approach which can be used to test people's views, opinions, knowledge, experiences or values from a set of qualitative data. It is a method of qualitative analysis where the data can be examined to identify common themes such as topics, ideas and patterns which come up repeatedly.

The characters of KSAs identified from the preliminary survey were checked and codes were assigned accordingly. Themes were generated based on the codes and the associated codes were then determined between the groups of KSAs identified from literature review and interviews. The repetition of KSAs was eliminated based on the identified associated codes. Themes and codes were reviewed again and the final set of KSAs was obtained from this qualitative analysis.
Overall, summary of the results obtained from the preliminary survey of this study is shown in Figure 1.

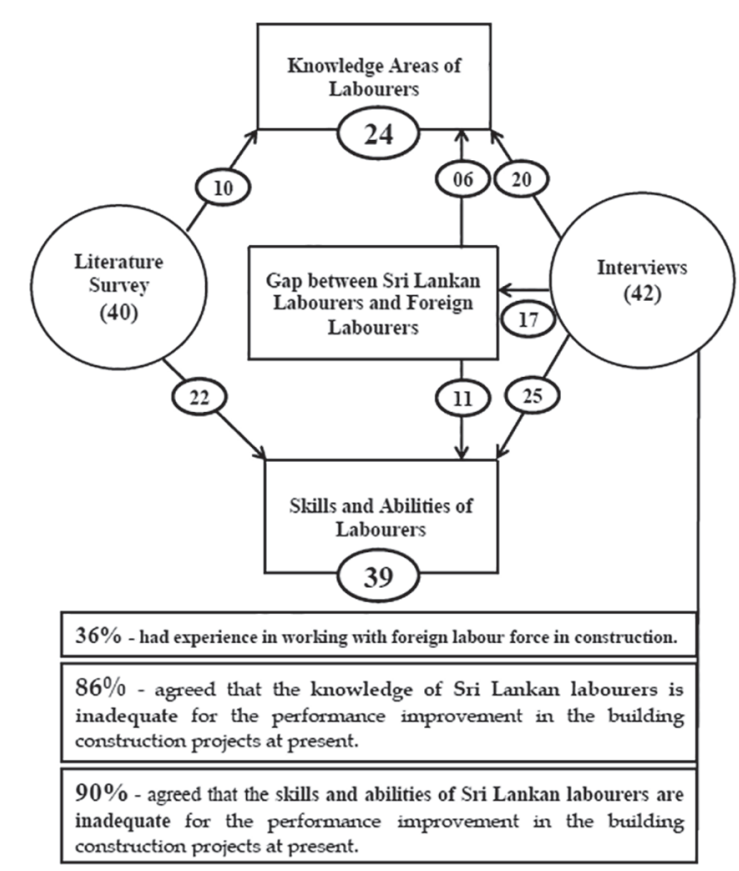

Figure 1 - Summary of the Preliminary Survey Results

\section{Questionnaire Survey}

A questionnaire survey was carried out among the building construction contractors in Sri Lanka to measure the severities of the identified KSAs of labourers influencing the performance improvement of the building construction projects. The KSAs identified from the preliminary survey of this study were included in the designed questionnaire. The questions were based on the Likert scale of five ordinal measures from 1 to 5 ( 1 represents the very low effect and 5 represents the very high effect). The validation of the questionnaire design was initially performed through getting the comments on the designed questionnaire from selected workers in different levels of working categories in the building construction projects in Sri Lanka.

The respondents to the questionnaire survey were found using snowball sampling method. Showk at \& Praveen [26] stated that the snowball sampling is a non-probability method of survey sample selection and it can be used when the potential participants are not easy to find. The survey was begun with a small number of known contractors and the sample size was then expanded through them to identify other contractors participated in this survey. 
Only construction contractors involved in building construction projects with a minimum 'C4' grade of CIDA registration were considered in this survey. In Sri Lanka, the contractors' registration is provided by the Construction Industry Development Authority (CIDA) with the necessary grades based on the contractors' financial availability, technical ability and experience gained in the field. The financial limit for ' $\mathrm{C} 4$ ' grade is between 50 million to 150 million Sri Lankan Rupees [LKR] [27]. A total of 154 responses were received from the building construction contractors in Sri Lanka in this survey. The no. of responses received based on the type of distribution and the contractor's grade of CIDA registration are shown in Table 4 and Table 5, respectively.

Table 4 - No. of Responses based on the Type of Distribution

\begin{tabular}{|l|c|}
\hline Type of Distribution & No. of Responses \\
\hline Post & 52 \\
\hline Direct handover & 87 \\
\hline Email & 15 \\
\hline
\end{tabular}

Table 5 - No. of Responses based on the Contractor's Grade of CIDA Registration

\begin{tabular}{|l|c|c|}
\hline $\begin{array}{l}\text { CIDA } \\
\text { Grade }\end{array}$ & $\begin{array}{c}\text { Financial Limit } \\
\text { of the Projects - } \\
\text { LKR in Millions }\end{array}$ & $\begin{array}{c}\text { No. of } \\
\text { Responses }\end{array}$ \\
\hline CS2 / CS1 & $X>1500$ & 07 \\
\hline C1 & $1500>=X>600$ & 23 \\
\hline C2 & $600>=X>300$ & 25 \\
\hline C3 & $300>=X>150$ & 25 \\
\hline C4 & $150>=X>50$ & 74 \\
\hline
\end{tabular}

According to the job designations of the responded individuals, they were divided into two working categories which are Director/ Managerial/ Engineer (DME) Level and Assistant Engineer/ Supervisor/ Technical Officer (AST) Level. The no. of responses received based on these two groups of workers is shown in Table 6. The no. of responses received based on the work experience of the respondents is shown in Table 7.

Table 6 - No. of Responses based on the Respondent's Job Designation

\begin{tabular}{|l|c|}
\hline $\begin{array}{l}\text { Respondent Job Designation } \\
\text { Category }\end{array}$ & $\begin{array}{c}\text { No. of } \\
\text { Responses }\end{array}$ \\
\hline DME Level & 90 \\
\hline AST Level & 64 \\
\hline
\end{tabular}

Table 7 - No. of Responses based on the Respondent's Work Experience

\begin{tabular}{|l|c|}
\hline $\begin{array}{l}\text { Experience in the } \\
\text { Construction Field }\end{array}$ & No. of Responses \\
\hline Less than 5 Years & 02 \\
\hline $5-10$ Years & 70 \\
\hline $11-15$ Years & 39 \\
\hline $16-20$ Years & 15 \\
\hline $21-25$ Years & 18 \\
\hline More than 25 Years & 10 \\
\hline
\end{tabular}

4.1 Relative Importance Index (RII)

Relative Importance Index (RII) method was used to determine the severity of each identified KSA on the performance of building construction projects. This can be calculated for each factor using the Equation (1) according to Dinh \& Nguyen [28].

$R I I=\Sigma W /(A * N)$

Where, $W$ - Weight assigned by response ranges (1 - Very Low, 2 - Low, 3 - Moderate, 4 High, 5 - Very High); A - Maximum weight given; $N$ - represents the total number of responses.

The following ranges of RII values were considered to obtain the level of the effects of KSAs. The KSAs which have RII values of 0.7 or above, were determined as critical.

- $\quad$ RII $>=0.9 \quad$ : Very High

- $0.9>$ RII $>=0.8 \quad$ : High

- $0.8>$ RII $>=0.7 \quad$ : High - Moderate

- $0.7>$ RII $>=0.6$ : Moderate

- $0.6>$ RII $>=0.5$ : Moderate - Low

- $0.5>$ RII $>=0.3 \quad$ : Low

- $0.3>$ RII : Very Low

Standard deviation, coefficient of variation and margin of error values were also calculated for each KSA to check the reliability of the results. The smaller standard deviation indicates that the values given by the respondents are around the mean values. Coefficient of variation is the ratio of standard deviation to the mean [29]. Margin of error value was calculated to each KSA for $95 \%$ confidence interval.

\subsection{Spearman's Coefficient of Rank Correlation}

Spearman's coefficient of rank correlation was used to identify the degree of agreement between DME level and AST level working categories on the KSAs of labourers in the building construction projects in Sri Lanka. This can be calculated using the Equation (2) 
according to Kesavan et al. [30] and Manoharan et al. [31].

$\rho=1-\left[6 \Sigma D^{2} / n\left(n^{2}-1\right)\right]$

Where, $\rho$ - Spearman's coefficient of rank correlation; $D$ - Difference between the ranks of two variables; $n$ - Number of observations

The following ranges of Spearman's coefficient of rank correlation values were considered to obtain the effects of degree of agreements.
- $\rho>0$
: Positive degree of agreement
- $\rho=0$
(Positive relationship)
- $0>\rho$
: Neutral (No correlation)
: Negative degree of agreement
(Negative relationship)

\section{Results}

\subsection{Severities of the KSAs of Labourers}

Levels of effect for the KSAs of labourers were determined based on their Relative Importance Index values as shown in Table 8 and Table 9. The results define impact level of each KSA of labourers influencing the performance of the building construction projects in Sri Lanka.

Table 8 - Ranking of Knowledge Areas of Labourers

\begin{tabular}{|c|c|c|c|c|c|c|c|c|c|c|c|c|c|c|c|c|c|c|}
\hline \multirow{2}{*}{$\begin{array}{c}\text { Knowledge } \\
\text { Areas }\end{array}$} & \multicolumn{6}{|c|}{ DME Level Workers' Perspective } & \multicolumn{6}{|c|}{ AST Level Workers' Perspective } & \multicolumn{6}{|c|}{ Overall } \\
\hline & RII & SD & $\mathrm{CV}$ & ME & $\#$ & LE & RII & SD & $\mathrm{CV}$ & ME & $\#$ & LE & RII & SD & $\mathrm{CV}$ & ME & $\#$ & LE \\
\hline $\begin{array}{l}\text { Construction } \\
\text { materials }\end{array}$ & 0.80 & 0.15 & 0.19 & 0.03 & 1 & $\mathrm{H}$ & 0.87 & 0.14 & 0.16 & 0.03 & 3 & $\mathrm{H}$ & 0.83 & 0.15 & 0.18 & 0.02 & 1 & $\mathrm{H}$ \\
\hline $\begin{array}{l}\text { Simple } \\
\text { measurements }\end{array}$ & 0.75 & 0.17 & 0.23 & 0.04 & 6 & HM & 0.90 & 0.15 & 0.17 & 0.04 & 1 & $\mathrm{VH}$ & 0.81 & 0.17 & 0.21 & 0.03 & 2 & $\mathrm{H}$ \\
\hline $\begin{array}{l}\text { Construction } \\
\text { methods, } \\
\text { procedures and } \\
\text { technology }\end{array}$ & 0.78 & 0.13 & 0.17 & 0.03 & 3 & HM & 0.85 & 0.13 & 0.15 & 0.03 & 4 & $\mathrm{H}$ & 0.81 & 0.14 & 0.17 & 0.02 & 2 & $\mathrm{H}$ \\
\hline Material handling & 0.74 & 0.17 & 0.23 & 0.04 & 7 & $\mathrm{HM}$ & 0.88 & 0.16 & 0.18 & 0.04 & 2 & $\mathrm{H}$ & 0.80 & 0.17 & 0.21 & 0.03 & 4 & $\mathrm{H}$ \\
\hline Numeracy & 0.79 & 0.12 & 0.15 & 0.02 & 2 & HM & 0.81 & 0.11 & 0.14 & 0.03 & 6 & $\mathrm{H}$ & 0.80 & 0.12 & 0.15 & 0.02 & 4 & $\mathrm{H}$ \\
\hline $\begin{array}{l}\text { Health and safety } \\
\text { in construction }\end{array}$ & 0.76 & 0.12 & 0.16 & 0.02 & 4 & HM & 0.83 & 0.14 & 0.17 & 0.03 & 5 & $\mathrm{H}$ & 0.79 & 0.14 & 0.18 & 0.02 & 6 & $\mathrm{HM}$ \\
\hline $\begin{array}{l}\text { Equipment } \\
\text { handling }\end{array}$ & 0.76 & 0.11 & 0.14 & 0.02 & 4 & $\mathrm{HM}$ & 0.76 & 0.12 & 0.16 & 0.03 & 11 & $\mathrm{HM}$ & 0.76 & 0.12 & 0.16 & 0.02 & 7 & $\mathrm{M}$ \\
\hline $\begin{array}{l}\text { Basic labour laws } \\
\text { and regulation }\end{array}$ & 0.71 & 0.15 & 0.21 & 0.03 & 9 & $\mathrm{HM}$ & 0.79 & 0.10 & 0.13 & 0.02 & 8 & $\mathrm{HM}$ & 0.74 & 0.13 & 0.18 & 0.02 & 8 & $\mathrm{HM}$ \\
\hline $\begin{array}{l}\text { Financial } \\
\text { knowledge }\end{array}$ & 0.72 & 0.16 & 0.22 & 0.03 & 8 & $\mathrm{HM}$ & 0.72 & 0.12 & 0.17 & 0.03 & 12 & $\mathrm{HM}$ & 0.72 & 0.16 & 0.22 & 0.03 & 9 & $\mathrm{HM}$ \\
\hline Psychology & 0.70 & 0.14 & 0.20 & 0.03 & 11 & $\mathrm{HM}$ & 0.71 & 0.13 & 0.18 & 0.03 & 13 & $\mathrm{HM}$ & 0.72 & 0.15 & 0.21 & 0.02 & 9 & $\mathrm{HM}$ \\
\hline $\begin{array}{l}\text { New technologies } \\
\text { in construction }\end{array}$ & 0.67 & 0.13 & 0.19 & 0.03 & 14 & $\mathrm{M}$ & 0.80 & 0.12 & 0.15 & 0.03 & 7 & $\mathrm{H}$ & 0.72 & 0.13 & 0.18 & 0.02 & 9 & $\mathrm{HM}$ \\
\hline Health science & 0.68 & 0.14 & 0.21 & 0.03 & 12 & $\mathrm{M}$ & 0.77 & 0.13 & 0.17 & 0.03 & 10 & $\mathrm{HM}$ & 0.72 & 0.15 & 0.21 & 0.02 & 9 & $\mathrm{HM}$ \\
\hline $\begin{array}{l}\text { Basic concepts of } \\
\text { structures }\end{array}$ & 0.67 & 0.16 & 0.24 & 0.03 & 14 & $\mathrm{M}$ & 0.79 & 0.13 & 0.16 & 0.03 & 8 & $\mathrm{HM}$ & 0.71 & 0.14 & 0.20 & 0.02 & 13 & $\mathrm{HM}$ \\
\hline $\begin{array}{l}\text { Quality assurance } \\
\text { and control in } \\
\text { construction }\end{array}$ & 0.71 & 0.14 & 0.20 & 0.03 & 9 & HM & 0.64 & 0.15 & 0.23 & 0.04 & 21 & $\mathrm{M}$ & 0.68 & 0.15 & 0.22 & 0.02 & 14 & $\mathrm{M}$ \\
\hline $\begin{array}{l}\text { Understanding } \\
\text { knowledge on } \\
\text { drawings }\end{array}$ & 0.66 & 0.13 & 0.20 & 0.03 & 18 & $\mathrm{M}$ & 0.68 & 0.11 & 0.16 & 0.03 & 15 & $\mathrm{M}$ & 0.68 & 0.13 & 0.19 & 0.02 & 14 & $\mathrm{M}$ \\
\hline $\begin{array}{l}\text { Waste } \\
\text { management }\end{array}$ & 0.67 & 0.14 & 0.21 & 0.03 & 14 & $\mathrm{M}$ & 0.68 & 0.13 & 0.19 & 0.03 & 15 & $\mathrm{M}$ & 0.68 & 0.14 & 0.21 & 0.02 & 14 & $\mathrm{M}$ \\
\hline $\begin{array}{l}\text { Water } \\
\text { management }\end{array}$ & 0.68 & 0.14 & 0.21 & 0.03 & 12 & $\mathrm{M}$ & 0.68 & 0.13 & 0.19 & 0.03 & 15 & $\mathrm{M}$ & 0.67 & 0.14 & 0.21 & 0.02 & 17 & $\mathrm{M}$ \\
\hline $\begin{array}{l}\text { Environmental } \\
\text { sustainability }\end{array}$ & 0.66 & 0.15 & 0.23 & 0.03 & 18 & $\mathrm{M}$ & 0.68 & 0.11 & 0.16 & 0.03 & 15 & $\mathrm{M}$ & 0.67 & 0.14 & 0.21 & 0.02 & 17 & M \\
\hline $\begin{array}{l}\text { Simple } \\
\text { architecture }\end{array}$ & 0.63 & 0.14 & 0.22 & 0.03 & 23 & $\mathrm{M}$ & 0.71 & 0.14 & 0.20 & 0.03 & 13 & $\mathrm{HM}$ & 0.67 & 0.14 & 0.21 & 0.02 & 17 & $\mathrm{M}$ \\
\hline Estimation & 0.67 & 0.17 & 0.25 & 0.04 & 14 & $\mathrm{M}$ & 0.67 & 0.13 & 0.19 & 0.03 & 19 & $\mathrm{M}$ & 0.67 & 0.16 & 0.24 & 0.03 & 17 & $\mathrm{M}$ \\
\hline $\begin{array}{l}\text { Environment and } \\
\text { society }\end{array}$ & 0.66 & 0.14 & 0.21 & 0.03 & 18 & $\mathrm{M}$ & 0.63 & 0.13 & 0.21 & 0.03 & 22 & $\mathrm{M}$ & 0.65 & 0.14 & 0.22 & 0.02 & 21 & $\mathrm{M}$ \\
\hline $\begin{array}{l}\text { English/ } \\
\text { Languages other } \\
\text { than mother } \\
\text { tongue }\end{array}$ & 0.64 & 0.16 & 0.25 & 0.03 & 21 & $\mathrm{M}$ & 0.67 & 0.19 & 0.28 & 0.05 & 19 & $\mathrm{M}$ & 0.64 & 0.17 & 0.27 & 0.03 & 22 & $\mathrm{M}$ \\
\hline Basic electricity & 0.64 & 0.14 & 0.22 & 0.03 & 21 & $\mathrm{M}$ & 0.61 & 0.14 & 0.23 & 0.03 & 23 & $\mathrm{M}$ & 0.63 & 0.15 & 0.24 & 0.02 & 23 & $\mathrm{M}$ \\
\hline $\begin{array}{l}\text { Information and } \\
\text { Communication } \\
\text { Technology }\end{array}$ & 0.59 & 0.17 & 0.29 & 0.04 & 24 & ML & 0.54 & 0.15 & 0.28 & 0.04 & 24 & ML & 0.57 & 0.18 & 0.28 & 0.03 & 24 & ML \\
\hline
\end{tabular}

RII: Relative Importance Index; SD: Standard Deviation; CV: Coefficient of Variation; ME: Margin of Error; \#: Rank; LE: Level of Effects; VH: Very High; H: High; HM: High - Moderate; M: Moderate; ML: Moderate - Low; L - Low; VL: Very Low 
Table 9 - Ranking of Skills and Abilities of Labourers

\begin{tabular}{|c|c|c|c|c|c|c|c|c|c|c|c|c|c|c|c|c|c|c|}
\hline \multirow{2}{*}{$\begin{array}{c}\text { Skills / } \\
\text { Abilities }\end{array}$} & \multicolumn{6}{|c|}{ DME Level Workers' Perspective } & \multicolumn{6}{|c|}{ AST Level Workers' Perspective } & \multicolumn{6}{|c|}{ Overall } \\
\hline & RII & SD & $\mathrm{CV}$ & ME & $\#$ & LE & RII & SD & $\mathrm{CV}$ & ME & $\#$ & LE & RII & SD & $\mathrm{CV}$ & ME & $\#$ & LE \\
\hline Attendance & 0.84 & 0.16 & 0.19 & 0.03 & 1 & $\mathrm{H}$ & 0.94 & 0.13 & 0.14 & 0.03 & 1 & VH & 0.88 & 0.15 & 0.17 & 0.02 & 1 & $\mathrm{H}$ \\
\hline Attitude & 0.83 & 0.17 & 0.20 & 0.04 & 2 & $\mathrm{H}$ & 0.94 & 0.13 & 0.14 & 0.03 & 1 & $\mathrm{VH}$ & 0.88 & 0.16 & 0.18 & 0.03 & 1 & $\mathrm{H}$ \\
\hline Communication & 0.83 & 0.17 & 0.20 & 0.04 & 2 & $\mathrm{H}$ & 0.93 & 0.14 & 0.15 & 0.03 & 3 & $\mathrm{VH}$ & 0.87 & 0.16 & 0.18 & 0.03 & 3 & $\mathrm{H}$ \\
\hline Punctuality & 0.83 & 0.16 & 0.19 & 0.03 & 2 & $\mathrm{H}$ & 0.92 & 0.14 & 0.15 & 0.03 & 4 & $\mathrm{VH}$ & 0.87 & 0.16 & 0.18 & 0.03 & 3 & $\mathrm{H}$ \\
\hline Commitment & 0.82 & 0.18 & 0.22 & 0.04 & 5 & $\mathrm{H}$ & 0.92 & 0.15 & 0.16 & 0.04 & 4 & VH & 0.86 & 0.17 & 0.20 & 0.03 & 5 & $\mathrm{H}$ \\
\hline Memorization & 0.80 & 0.18 & 0.23 & 0.04 & 6 & $\mathrm{H}$ & 0.91 & 0.16 & 0.18 & 0.04 & 6 & $\mathrm{VH}$ & 0.85 & 0.18 & 0.21 & 0.03 & 6 & $\mathrm{H}$ \\
\hline $\begin{array}{l}\text { Reduction of } \\
\text { alcohol and drugs } \\
\text { usage }\end{array}$ & 0.78 & 0.19 & 0.24 & 0.04 & 8 & HM & 0.88 & 0.15 & 0.17 & 0.04 & 7 & $\mathrm{H}$ & 0.82 & 0.18 & 0.22 & 0.03 & 7 & $\mathrm{H}$ \\
\hline $\begin{array}{l}\text { Measuring } \\
\text { skills/abilities }\end{array}$ & 0.80 & 0.14 & 0.18 & 0.03 & 6 & $\mathrm{H}$ & 0.84 & 0.13 & 0.15 & 0.03 & 8 & $\mathrm{H}$ & 0.81 & 0.14 & 0.17 & 0.02 & 8 & $\mathrm{H}$ \\
\hline $\begin{array}{l}\text { Understanding } \\
\text { with other } \\
\text { workers }\end{array}$ & 0.78 & 0.14 & 0.18 & 0.03 & 8 & HM & 0.84 & 0.13 & 0.15 & 0.03 & 8 & $\mathrm{H}$ & 0.81 & 0.14 & 0.17 & 0.02 & 8 & $\mathrm{H}$ \\
\hline $\begin{array}{l}\text { Reading, writing } \\
\text { and listening }\end{array}$ & 0.77 & 0.17 & 0.22 & 0.04 & 10 & HM & 0.84 & 0.13 & 0.15 & 0.03 & 8 & $\mathrm{H}$ & 0.80 & 0.16 & 0.20 & 0.03 & 10 & $\mathrm{H}$ \\
\hline Learning & 0.75 & 0.18 & 0.24 & 0.04 & 11 & HM & 0.83 & 0.15 & 0.18 & 0.04 & 11 & $\mathrm{H}$ & 0.78 & 0.18 & 0.23 & 0.03 & 11 & $\mathrm{HM}$ \\
\hline Critical reasoning & 0.74 & 0.16 & 0.22 & 0.03 & 15 & HM & 0.83 & 0.14 & 0.17 & 0.03 & 11 & $\mathrm{H}$ & 0.78 & 0.16 & 0.21 & 0.03 & 11 & $\mathrm{HM}$ \\
\hline Physical ability & 0.75 & 0.13 & 0.17 & 0.03 & 11 & HM & 0.78 & 0.14 & 0.18 & 0.03 & 15 & $\mathrm{HM}$ & 0.76 & 0.14 & 0.18 & 0.02 & 13 & $\mathrm{HM}$ \\
\hline Material handling & 0.75 & 0.10 & 0.13 & 0.02 & 11 & HM & 0.73 & 0.11 & 0.15 & 0.03 & 17 & HM & 0.74 & 0.11 & 0.15 & 0.02 & 14 & HM \\
\hline $\begin{array}{l}\text { Math and } \\
\text { language literacy }\end{array}$ & 0.70 & 0.19 & 0.27 & 0.04 & 28 & HM & 0.80 & 0.16 & 0.20 & 0.04 & 13 & $\mathrm{H}$ & 0.74 & 0.18 & 0.24 & 0.03 & 14 & $\mathrm{HM}$ \\
\hline Psychology & 0.70 & 0.14 & 0.20 & 0.03 & 28 & $\mathrm{HM}$ & 0.79 & 0.16 & 0.20 & 0.04 & 14 & $\mathrm{HM}$ & 0.74 & 0.16 & 0.22 & 0.03 & 14 & $\mathrm{HM}$ \\
\hline $\begin{array}{l}\text { Equipment/ Tool } \\
\text { handling }\end{array}$ & 0.74 & 0.13 & 0.18 & 0.03 & 15 & HM & 0.73 & 0.11 & 0.15 & 0.03 & 17 & $\mathrm{HM}$ & 0.74 & 0.13 & 0.18 & 0.02 & 14 & $\mathrm{HM}$ \\
\hline Concreting & 0.75 & 0.12 & 0.16 & 0.02 & 11 & HM & 0.72 & 0.12 & 0.17 & 0.03 & 20 & $\mathrm{HM}$ & 0.73 & 0.12 & 0.16 & 0.02 & 18 & $\mathrm{HM}$ \\
\hline Problem solving & 0.74 & 0.16 & 0.22 & 0.03 & 15 & HM & 0.72 & 0.17 & 0.24 & 0.04 & 20 & HM & 0.73 & 0.16 & 0.22 & 0.03 & 18 & $\mathrm{HM}$ \\
\hline Estimating & 0.70 & 0.16 & 0.23 & 0.03 & 28 & $\mathrm{HM}$ & 0.75 & 0.14 & 0.19 & 0.03 & 16 & $\mathrm{HM}$ & 0.72 & 0.15 & 0.21 & 0.02 & 20 & $\mathrm{HM}$ \\
\hline $\begin{array}{l}\text { Skills in team } \\
\text { work }\end{array}$ & 0.72 & 0.13 & 0.18 & 0.03 & 19 & HM & 0.71 & 0.14 & 0.20 & 0.03 & 22 & $\mathrm{HM}$ & 0.72 & 0.14 & 0.19 & 0.02 & 20 & $\mathrm{HM}$ \\
\hline $\begin{array}{l}\text { Ability to } \\
\text { understand } \\
\text { drawings }\end{array}$ & 0.71 & 0.16 & 0.23 & 0.03 & 22 & HM & 0.73 & 0.18 & 0.25 & 0.04 & 17 & $\mathrm{HM}$ & 0.72 & 0.18 & 0.25 & 0.03 & 20 & $\mathrm{HM}$ \\
\hline Bar bending & 0.73 & 0.14 & 0.19 & 0.03 & 18 & HM & 0.69 & 0.12 & 0.17 & 0.03 & 23 & $\mathrm{M}$ & 0.71 & 0.12 & 0.17 & 0.02 & 23 & $\mathrm{HM}$ \\
\hline Plastering & 0.72 & 0.15 & 0.21 & 0.03 & 19 & $\mathrm{HM}$ & 0.67 & 0.13 & 0.19 & 0.03 & 28 & $\mathrm{M}$ & 0.70 & 0.13 & 0.19 & 0.02 & 24 & $\mathrm{HM}$ \\
\hline Plumbing & 0.71 & 0.16 & 0.23 & 0.03 & 22 & HM & 0.69 & 0.12 & 0.17 & 0.03 & 23 & $\mathrm{M}$ & 0.70 & 0.12 & 0.17 & 0.02 & 24 & HM \\
\hline Brickworks & 0.71 & 0.15 & 0.21 & 0.03 & 22 & HM & 0.68 & 0.12 & 0.18 & 0.03 & 26 & $M$ & 0.70 & 0.13 & 0.19 & 0.02 & 24 & $\mathrm{HM}$ \\
\hline Tiling & 0.71 & 0.14 & 0.20 & 0.03 & 22 & $\mathrm{HM}$ & 0.68 & 0.12 & 0.18 & 0.03 & 26 & $\mathrm{M}$ & 0.70 & 0.13 & 0.19 & 0.02 & 24 & $\mathrm{HM}$ \\
\hline Painting & 0.72 & 0.17 & 0.24 & 0.04 & 19 & HM & 0.66 & 0.16 & 0.24 & 0.04 & 30 & $M$ & 0.70 & 0.13 & 0.19 & 0.02 & 24 & $\mathrm{HM}$ \\
\hline $\begin{array}{l}\text { Ability to adapt to } \\
\text { changes in } \\
\text { environments }\end{array}$ & 0.71 & 0.18 & 0.25 & 0.04 & 22 & HM & 0.66 & 0.19 & 0.29 & 0.05 & 30 & $\mathrm{M}$ & 0.69 & 0.19 & 0.28 & 0.03 & 29 & $\mathrm{M}$ \\
\hline $\begin{array}{l}\text { Decision making } \\
\text { skills/abilities }\end{array}$ & 0.69 & 0.14 & 0.20 & 0.03 & 33 & $\mathrm{M}$ & 0.69 & 0.13 & 0.19 & 0.03 & 23 & $\mathrm{M}$ & 0.69 & 0.14 & 0.20 & 0.02 & 29 & $\mathrm{M}$ \\
\hline Welding & 0.70 & 0.16 & 0.23 & 0.03 & 28 & HM & 0.66 & 0.15 & 0.23 & 0.04 & 30 & $\mathrm{M}$ & 0.69 & 0.14 & 0.20 & 0.02 & 29 & $\mathrm{M}$ \\
\hline Carpentry & 0.70 & 0.18 & 0.26 & 0.04 & 28 & HM & 0.66 & 0.17 & 0.26 & 0.04 & 30 & $\mathrm{M}$ & 0.68 & 0.14 & 0.21 & 0.02 & 32 & $\mathrm{M}$ \\
\hline $\begin{array}{l}\text { Working with } \\
\text { electrical sources }\end{array}$ & 0.69 & 0.17 & 0.25 & 0.04 & 33 & $\mathrm{M}$ & 0.67 & 0.15 & 0.22 & 0.04 & 28 & $\mathrm{M}$ & 0.68 & 0.15 & 0.22 & 0.02 & 32 & $\mathrm{M}$ \\
\hline $\begin{array}{l}\text { Leadership } \\
\text { skills/abilities }\end{array}$ & 0.71 & 0.17 & 0.24 & 0.04 & 22 & HM & 0.61 & 0.17 & 0.28 & 0.04 & 34 & $M$ & 0.67 & 0.17 & 0.25 & 0.03 & 34 & $\mathrm{M}$ \\
\hline $\begin{array}{l}\text { Planning } \\
\text { skills/abilities }\end{array}$ & 0.69 & 0.17 & 0.25 & 0.04 & 33 & $\mathrm{M}$ & 0.57 & 0.16 & 0.28 & 0.04 & 35 & ML & 0.64 & 0.17 & 0.27 & 0.03 & 35 & $\mathrm{M}$ \\
\hline $\begin{array}{l}\text { Analytical skills/ } \\
\text { abilities }\end{array}$ & 0.66 & 0.19 & 0.29 & 0.04 & 36 & $\mathrm{M}$ & 0.49 & 0.14 & 0.29 & 0.03 & 38 & L & 0.59 & 0.16 & 0.27 & 0.03 & 36 & $\overline{M L}$ \\
\hline $\begin{array}{l}\text { Multiple work } \\
\text { coordination }\end{array}$ & 0.65 & 0.18 & 0.28 & 0.04 & 37 & $\mathrm{M}$ & 0.49 & 0.13 & 0.27 & 0.03 & 38 & L & 0.58 & 0.16 & 0.28 & 0.03 & 37 & ML \\
\hline $\begin{array}{l}\text { Management/ } \\
\text { organizational } \\
\text { skills }\end{array}$ & 0.64 & 0.17 & 0.27 & 0.04 & 38 & $\mathrm{M}$ & 0.50 & 0.14 & 0.28 & 0.03 & 37 & ML & 0.58 & 0.15 & 0.26 & 0.02 & 37 & ML \\
\hline $\begin{array}{l}\text { Innovative } \\
\text { thinking }\end{array}$ & 0.62 & 0.16 & 0.26 & 0.03 & 39 & $\mathrm{M}$ & 0.51 & 0.15 & 0.29 & 0.04 & 36 & ML & 0.58 & 0.16 & 0.28 & 0.03 & 37 & ML \\
\hline
\end{tabular}

RII: Relative Importance Index; SD: Standard Deviation; CV: Coefficient of Variation; ME: Margin of Error; \#: Rank; LE: Level of Effects; VH: Very High; H: High; HM: High - Moderate; M: Moderate; ML: Moderate - Low; L - Low; VL: Very Low

Overall, a total of 13 knowledge areas and 28 skills/abilities were identified as the critical KSAs of labourers influencing the performance of the building construction projects in Sri Lanka. The labourer's knowledge of construction materials, measurements and construction methods were found at the top three ranked knowledge areas, where the labourers' attendance, attitude and communication skills were at the top three in the category of skills/abilities. Considering DME level workers' perspective, a total of 11 knowledge areas and 32 skills/abilities were identified as the critical KSAs of labourers. There were 14 knowledge areas and 22 skills/abilities identified as critical based on 
AST level workers' perspective. The top five ranking KSAs in each category were considered as significant to improve the performance of construction by a number of studies over the past as shown in Table 10.

Table 10 - Comparison of Top Five Ranking KSAs with Past Studies

\begin{tabular}{|c|c|c|c|}
\hline & \# & KSAs & Past Studies \\
\hline \multirow{5}{*}{ 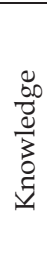 } & 1 & Construction materials & Praveen et al. [24]; Tertiary and Vocational Education Commission [3] \\
\hline & 2 & Simple measurements & Dolage et al. [32]; Praveen et al. [24]; Mistry \& Bhatt [5] \\
\hline & 3 & $\begin{array}{l}\text { Construction methods, } \\
\text { procedures and technology }\end{array}$ & Serdar \& Jasper [7]; Parviz \& Hosseini [6]; Mistry \& Bhatt [5]; Biren et al. [4] \\
\hline & 4 & Material handling & Dolage et al. [32]; Praveen et al. [24] \\
\hline & 5 & Numeracy & Praveen et al. [24]; Tertiary and Vocational Education Commission [3] \\
\hline \multirow{5}{*}{ 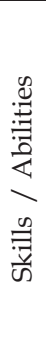 } & 1 & Attendance & $\begin{array}{l}\text { Lim \& Jahidul [11]; Mostafa \& Khaled [9]; Soekiman et al. [33]; } \\
\text { Shashank et al. [34]; Rami \& David [19] }\end{array}$ \\
\hline & 2 & Attitude & $\begin{array}{l}\text { Soekiman et al. [33]; Dharani [17]; Fernando et al. [2]; Orando \& Isabirye [14]; } \\
\text { Dinh \& Nguyen [28] }\end{array}$ \\
\hline & 3 & Communication & Robles et al. [13]; Rami \& David [19] \\
\hline & 4 & Punctuality & $\begin{array}{l}\text { Brent \& Leighton [12]; Shashank et al. [34]; Dharani [17]; Fernando et al. [2]; } \\
\text { Orando \& Isabirye [14] }\end{array}$ \\
\hline & 5 & Commitment & Aynur et al. [18]; Mostafa \& Khaled [9]; Saurav et al. [8]; Onyekachi [35] \\
\hline
\end{tabular}

\section{2}

Degree of Agreement between the Levels of Workers

The Spearman's rank coefficient of correlation was applied to measure the degree of agreement or disagreement between DME level and AST level workers on the KSAs of labourers in the building construction projects in Sri Lanka. The results indicate $74.4 \%$ of the degree of agreement (positive relationship) is between those two working categories in the knowledge areas of labourers. There is an $84.3 \%$ degree of agreement (positive relationship) between them with the skills and abilities of labourers. The results confirm that there are not many differences of ideas between DME level workers and AST level workers on the KSAs of labourers identified.

\subsection{Validity/Reliability of the Findings}

The standard deviation (SD) and coefficient of variation $(\mathrm{CV})$ values of the KSAs ensure the reliability and precision of the findings. The $\mathrm{CV}$ values are less than 0.3 for the KSAs in all categories. According to the Labour Force Survey Guide 2020 of Canada [36], these CV values ensure that the validity and reliability of the findings are at satisfactory level for the purpose of this study. The degree of agreement obtained between the observations of two working categories on the KSAs also confirms the reliability of these findings.

\section{Conclusions}

The study identified the significant knowledge areas, skills and abilities of the labourers with the severity values considering the performance improvement in the building construction projects in Sri Lanka. The overall results show that the industry should give special attention to improving the work-related cognitive and self-management skills of the labourers than their transferable and technical skills.

The study also highlights the urgent need for improving the training programmes for the labourers working in the construction projects in Sri Lanka. The necessary workplace training activities and experimental exercises should be developed to apply better practices into the labour operations based on the critical KSAs identified from this study. The severity levels of the KSAs presented in this study will be very useful to the training providers and skill development authorities for making necessary improvements in the existing training programmes. These results will also be helpful to the curriculum developers for designing new training programmes based on the industry's requirements, especially to design the learning outcomes, learning contents and delivery methods. The study recommends designing a proper system to evaluate labour skills in the worksites of the Sri Lankan construction firms. The construction companies are highly advised to pay more attention to skill improvement 
practices and performance evaluation methods for the labourers in Sri Lanka.

The findings of this study are expected to be highly beneficial to the construction companies, skill development authorities and training providers in Sri Lanka in order to take necessary actions for improvement. Some of these findings may also be tested by other developing construction industries in similar scenarios. It is recommended that the future studies should focus more on improving practices based on the critical KSAs of labourers illustrated in this article.

\section{Acknowledgements}

The authors wish to acknowledge the construction professionals who actively participated in the interviews and the questionnaire survey of this study. The authors wish to thank Tertiary and Vocational Education Commission of Sri Lanka (TVEC-SL), Vocational Training Authority of Sri Lanka (VTASL), Construction Industry Development Authority (CIDA) and Wayamba University of Sri Lanka (WUSL) for providing valuable support in the resource arrangements of this study. The authors would also like to express sincere and heartfelt gratitude to the Department of Civil Engineering of the University of Peradeniya for the support provided during the study.

\section{References}

1. Anil, M., Chitranjan, G. P., \& Jayeshkumar, R. P., "Analysis of Causes, Effects and Impacts of Skills Shortage for Sustainable Construction through Analytic Hierarchy Process", Int J Tech Innov Mod Eng Sci, Vol. 5, No. 5, pp. 168-176, 2019.

2. Fernando, P. G. D., Fernando, N. G., \& Gunarathna, M. A. C. L., "Skills Developments of Labourers to Achieve the Successful Project Delivery in the Sri Lankan Construction Industry", J Civ Environ Res, Vol. 8, No. 5, pp. 8699, 2016.

3. Tertiary and Vocational Education Commission, Construction Industry Sector Training Plan 2018 - 2020, Sri Lanka, 2018.

4. Biren, P., Bhavsar, J. J., \& Jayeshkumar P., “A Critical Literature Review of Labour Productivity in Building Construction", Int J Constr Res Civ Eng, Vol. 3, No. 4, pp. 2454-8693, pp. 76-80, 2017.
5. Mistry, S., \& Bhatt, R., "Critical Factors Affecting Labour Productivity in Construction Projects: Case Study of South Gujarat Region of India", Int J of Eng Adv Tech, Vol. 2, No. 4, pp. 583-591, 2013.

6. Parviz, G., \& Mohammad, R. H., "A Survey of the Factors Affecting the Productivity of Construction Projects in Iran", Tech Econ Dev Economy, Vol. 18, No. 1, pp. 99-116, 2012.

7. Serdar, D., \& Jasper, M., “On-site Labour Productivity of New Zealand Construction Industry: Key Constraints and Improvement Measures", Australasian J Constr Econ Build, Vol. 11, No. 3 pp. 18-33, 2011.

8. Saurav, D., Amit, K. P., Satya, N. M., \& Sanjeev, B., "A Study of Enabling Factors Affecting Construction Productivity: Indian Scenario", Int J Civ Eng Tech, Vol. 8, No. 6, pp. 741-758, 2017.

9. Mostafa, E. S. \& Khaled, M. E. G., “Towards Improving Construction Labor Productivity and Projects' Performance", Alex Eng J, Vol. 50, pp. 321-330, 2011.

10. Peter, F. K, Paul, O. O., Gary, D. H., \& Frank, C.H., "Factors Influencing Craftsmen's Productivity in Indonesia", Int J Proj Manage, Vol. 15, No. 1, pp. 21-30, 1997.

11. Lim, E. C., \& Jahidul A., "Construction Productivity: Issues Encountered by Contractors in Singapore", Int J Proj Manage, Vol. 13, No. 1, pp. 51-58, 1995.

12. Brent, G. H., \& Leighton, A. E., "Factors affecting Construction Labour Productivity in Trinidad and Tobago", J Assoc Prof Eng Trinidad Tobago, Vol.42, No.1, pp.4-11, 2013.

13. Robles, G., Stifi, A., José, L. P. T., \& Gentes, S., "Labor Productivity in the Construction Industry - Factors Influencing the Spanish Construction Labor Productivity", World Acad Sci Eng Tech Int J Civ Environ Eng, Vol. 8, No.10, pp. 1061-1070, 2014.

14. Orando, M., \& Isabirye, A. K., "Construction Workers' Skill Development: A strategy for Improving Capacity and Productivity in South Africa", Int J Econ Finance Stud, Vol. 10, No. 1, pp. 66-80, 2018.

15. Rasool, F., \& Botha, C. J., "The Nature, Extent and Effect of Skills Shortages on Skills Migration in South Africa", SA I Hum Res Manage, Vol. 9, No. 1, 1-12, 2011.

16. Silva, G. A. S. K., Warnakulasuriya, B. N. F., \& Arachchige, B. J. H., "A Review of the Skill Shortage Challenge in Construction Industry in 
Sri Lanka", Int J Econ Bus Manage Res, Vol. 2, No. 1, pp. 75-89, 2018.

17. Dharani, K., "Study on Labours Productivity Management in Construction Industry", Int J Latest Trends Eng Tech, Vol. 6, No. 1, pp. 278284, 2015.

18. Aynur, K., Ekrem, M. \& Serdar, U., "Effect of Basic Motivational Factors on Construction Workforce Productivity in Turkey", J Civ Eng Manage, Vol. 14, No. 2, pp. 95-106, 2008.

19. Rami, H., \& David, T., "A Review of Enabling Factors in Construction Industry Productivity in an Australian Environment", Constr Innov, Vol. 14, No. 2, pp. 210-228, 2014.

20. Peter, U. O., John, U. E. \& Fidelis, O. E., "Building Construction Workers' Health and Safety Knowledge and Compliance on Site", J Saf Eng, Vol. 5, No. 1, pp. 17-26, 2016.

21. Oseghale, B. O., Abiola-Falemu, J. O. \& Oseghale, G. E., "An Evaluation of Skilled Labour Shortage in Selected Construction Firms in Edo State, Nigeria", Am J Eng Res, Vol. 4, No. 1, pp. 156-167, 2015.

22. Shahab, S., \& Audrius, B., "Application of Fuzzy Fault Tree Analysis to Identify Factors Influencing Construction Labor Productivity: A High-rise Building Case Study", J Civ Eng Manage, Vol. 25, No. 1, pp. 41-52, 2018.

23. Abdulaziz, M. J., Charles, Y. K. \& Jamal, H. Y., "A Survey of Factors Influencing the Productivity of Construction Operatives in the State of Qatar", Int J of Constr Manage, Vol. 12, No. 3, pp. 1-23, 2012.

24. Praveen R., Niththiyananthan, T., Kanarajan, S. \& Dissanayake, P. B. G., "Shortage of Skilled Labour and Professionals in the Construction Industry of Sri Lanka", Transactions of the Institution of Engineers Sri Lanka 2011, Vol. I(B), pp. 239-247, 2011.

25. Caulfield, J., "How to do thematic analysis?", https://www.scribbr.com/methodology/them atic-analysis/, Visited, 16th October 2019.

26. Showkat, N., \& Parveen, H., Non Probability and Probability Sampling, e-PG Pathshala Publishers, 1-9 p., 2017.

27. Construction Industry Development Authority, National Registration and Grading Scheme for Construction Contractors, http://www.cida.gov.lk/sub_pgs/con_registr ation.html, Visited, 12th October 2019.

28. Dinh, T. H., \& Nguyen. V. T., "Analysis of Affected Factors on Construction Productivity in Vietnam", Int J Civ Eng Tech, Vol. 10, No. 2, pp. 854-864, 2019.

29. Solly, M. S., Gezani, R. M., “Construction and Application of a Statistical Test for Coefficient of Variation on Normal Distributions", Am J Appl Sci, Vol. 14, No. 11, 1024-1030, 2017.

30. Kesavan, M., Gobidan, N. N., Dissanayake, P.B.G., "Analysis of Factors Contributing Civil Engineering Project Delays in Sri Lanka", in Proceedings of the Session on Construction Management and Tall Building and Urban Habitat, $6^{\text {th }}$ International Conference on Structural Engineering and Construction Management 2015, Vol. 4, pp 40-46, 2015.

31. Manoharan, K., Navanesan, G., \& Pujitha, D., "Analysis of Factors Contributing Civil Engineering Construction Project Delays in Sri Lankan Building Construction Industries", J Ind Eng Res, Vol. 1, No. 7, pp. 5-11, 2015.

32. Dolage, D. A. R., Wijesundara, W. R. G. A., Nandasiri, D. G., "Analysis of User Problems in Construction Machinery Hiring, Engineer", J Inst Eng Sri Lanka, Vol. 43, No. 1, pp. 32-41, 2010.

33. Soekiman, A., Pribadi, K. S., Soemardi, B. W., Wirahadikusumah, R. D., "Factors Relating to Labor Productivity Affecting the Project Schedule Performance in Indonesia", Procedia Eng, Vol. 14, pp. 865-873, 2011.

34. Shashank, K., Sutapa, H., Kabindra, N. P., "Analysis of Key Factors Affecting the Variation of Labour Productivity in Construction Projects", Int J Emerg Tech Adv Eng, Vol. 4, No. 5, pp. 152-160, 2014.

35. Onyekachi, V. N., "Impact of Low Labour Characteristics on Construction Sites Productivity in EBONYI State", Int J Adv Res Sci Eng Tech, Vol. 5, No. 10, pp. 7072-7087, 2018.

36. Statistics Canada, Guide to the Labour Force Survey 2020, Canada, 2020. 